\title{
Composite of Poly Lactid Co-Glycolic Acid (PLGA)-Collagen Coated by Chitosan as Candidate of Hollow Fiber Small Diameter Vascular Graft
}

\author{
Prihartini Widiyanti ${ }^{1,2, a}$, Dita Ayu Mayasari ${ }^{2, b}$, Zahrina Mardina ${ }^{2, c}$, \\ Riki Siswanto ${ }^{2}$, Agresta Afianti Ifada ${ }^{2}$, Ova Oktavina ${ }^{2}$ \\ ${ }^{1}$ Institute of Tropical Disease, Airlangga University, Surabaya, Indonesia \\ ${ }^{2}$ Biomedical Engineering Program, Faculty of Science and Technology, Airlangga University, \\ Surabaya, Indonesia \\ adrwidiyanti@yahoo.com, 'bmayasari.dita@ymail.com, 'mardinazahrina@yahoo.com
}

\section{Keywords: Chitosan, Collagen, PLGA, Hollow fiber, Vascular Graft}

\begin{abstract}
Heart failure is a serious major health problem with high number of mortality per year. Bypass is one of solutions that has often been taken. Nowadays, synthetic materials have been fabricated from polymers to solve disadvantages which are provided by autograft, allograft and xenograft. The aim of this research is to make a synthetic vascular graft with great physical strength, high biocompatibility, and good affordability. The method of this research was mixing PLGA and collagen by magnetic stirrer. This composite were shaped by spinneret with water as coagulant. Then it was coated by chitosan with 3 variations of weight ( $1 \% \mathrm{wt}, 2 \% \mathrm{wt}$, and $3 \% \mathrm{wt})$ to increase hemo and cytocompatibility, proliferation, and cell attachment in order to make vascular graft candidates to be more biocompatible. Mechanical strength for each variation was 5,306 $\mathrm{MPa}$ (chitosan $1 \% \mathrm{wt}$ ), 3,433 MPa (chitosan $2 \% \mathrm{wt}$ ) and 3,745 $\mathrm{MPa}$ (chitosan $3 \% \mathrm{wt}$ ). All tensile values were higher than human vascular tensile strength. Toxicity test showed that living cells in all variations were more than $60 \%$ in number, thus this vascular graft is not toxic.Hemolytic assay showed that the lowest coagulation was provided by sample with $3 \%$ wt chitosan.
\end{abstract}

\section{Introduction}

Heart failure is a major health problem. The prevalence of heart failure has tendency to be increased year by year. Most of patients diagnosed with heart failure still have around five years of life expectancy. There were approximately 250.000 patients died because heart failure each year, and that number has increased 6 times in last 40 years. The usage of natural materials or synthetic materials to replace part of a blood vessel in patient's recovery efforts has become very necessary [1].

The vascular graft which are made from pig aorta, bovine endothelial cell, rat cortex cerebral, or other xenograft materials (from another species) could hardly be developed in Indonesia due to several ethical problems and unsuitable societal paradigm. Stem cell development mainly the usage of non sterile medium such xenograft might cause zoonotic infection for human.

Even stem-cell-based medication of heart failure is believed to be future solution, this method is still unable to produce dramatic solving and cannot be practiced widely. One of reasons is the fact that only $0.5-5 \%$ of injected stem cells remain in targetted tissue while the rest just go through. Stem cell process is also very costly and time-consuming. In addition, there is also a problem to avoid contamination in laboratory. Moreover, when the product of stem cell is ready to be used, the cost which must be paid by the patient is very high. In contrary, there are more feasible procedures with other materials that could be done to minimize financial problem of heart failure and arteriosclerotic patients. Thus, a vascular graft made of synthetic polymers is developed. In the world, nowadays, polymers that have been used for vascular graft are PET, PTFE, Dacron, and several others. Each type of artificial vascular graft has advantages and disadvantages when viewed from its strength and biocompatibility. This study has been used Poly-L glycolic (PLGA). Lactid 
glycolic acid compound itself tends to be not toxic because it is actually also a byproduct of metabolism. According to aforementioned backgrounds, an innovation of producing a vascular graft based on synthetic material Poly Lactid co Glycolic acid (PLGA) coated by chitosan in the form of micron hollow fiber was developed in this research. The purpose of using chitosan was to increase material's hemocompatibility and cytocompatibility, cell proliferation, and cell attachment. The PLGA was combined with bovine bone collagen to get a better modulus of elasticity that shown by ultimate tensile strength [2].

\section{Materials and method}

\section{Materials}

The materials used in this study were PLGA (Mw 100.000), DMF as solvent, bovine bone collagen, chitosan, acetic acid as solvent of chitosan, spinneret, and dip coating properties.

\section{Method}

There were three process of creating hollow fiber PLGA. The first process was creating a homogenous solution. PLGA and bovine bone collagen were solved in DMF with concentration of $46 \%$. Composition of solute was $76 \%$ PLGA and $24 \%$ bovine bone collagen. Solution was stirred without heating with velocity of radian $100 \mathrm{rpm}$ for 5 hours. After that, solution was put in refrigerator for 24 hours. The second process was creating a hollow fiber with spinneret. The inert Nitrogen gasses were used to push solution out from syringe. The coagulant used in this process was water. The distance between the end of syringe and the coagulant bath was $2 \mathrm{~cm}$. The result of spinneret can be seen on figure 1 .

The third process was coating hollow fiber with chitosan. There were three variation of chitosan concentration $1 \% \mathrm{wt}, 2 \% \mathrm{wt}$, and 3\%wt. Chitosan was dissolved in acetic acid. Then, the hollow fiber was dipped in chitosan solution for 2 hours and dried with oven in temperature of $40^{\circ} \mathrm{C}$ for 24 hours.



Fig 1. Hollow fiber PLGA-bovine bone collagens

The fourth process was mechanical, biological, chemical and physical characterization. Mechanical characterization was tensile strength test with autograph. Cytotoxicity test as biological characterization used MTT Assay. The physical characterization was microscopy test used scanning electron micrograph and chemical characterization was hemocompatibility test used hemolysis method.

\section{Results}

\section{Ultimate Tensile Strength}

The mechanical properties evaluations were done to acquire the values of hollow fiber's mechanical quality. A tensile strength test was done with two repetitions. 
Table 1. Result of Tensile Strength Test

\begin{tabular}{cc}
\hline $\begin{array}{c}\text { Sample } \\
\text { (concentration of chitosan) }\end{array}$ & $\begin{array}{c}\text { Ultimate Tensile Strength } \\
(\mathrm{MPa})\end{array}$ \\
\hline $1 \% \mathrm{wt}$ & 5.306 \\
$2 \% \mathrm{wt}$ & 3.433 \\
$3 \% \mathrm{wt}$ & 3.745 \\
\hline
\end{tabular}

The extension rate of autograph used in this research was $5 \mathrm{~mm} /$ minute. The average diameter of hollow fiber sample tested in autograph was $2 \mathrm{~mm}$.

\section{Cytotoxicity Test}

The second evaluation was cytotoxicity test using Baby Hamster Kidney cell 21 (BHK 21) by MTT assay method.

Table 2. MTT Assay Result

\begin{tabular}{ccccc}
\hline $\begin{array}{c}\text { Sample } \\
\text { (concentration of } \\
\text { chitosan) }\end{array}$ & OD Media Control & OD Cell Control & OD Sample & \% Live Cell \\
\hline $1 \% \mathrm{wt}$ & 0.129 & 0.125 & 0.117 & 95.7 \\
$2 \% \mathrm{wt}$ & 0.130 & 0.124 & 0.105 & 92.5 \\
$3 \% \mathrm{wt}$ & 0.126 & 0.120 & 0.110 & 95.7 \\
\hline
\end{tabular}

\section{Morphological}

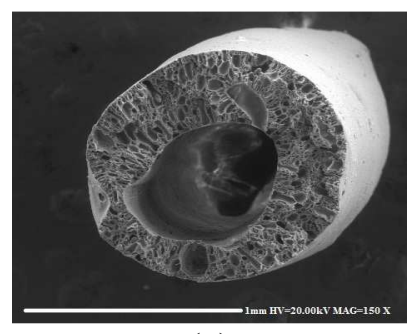

(a)

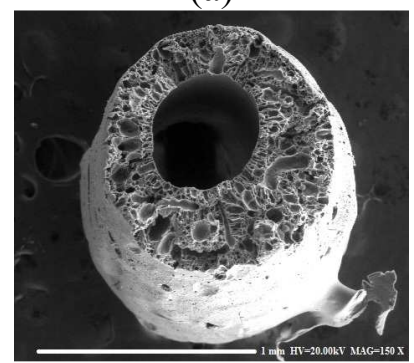

(c)

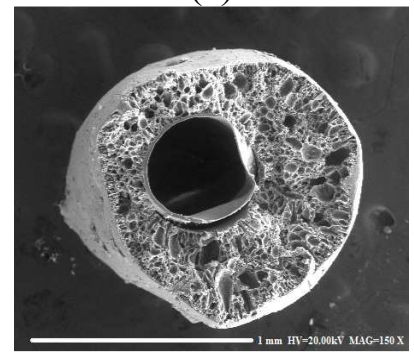

(e)

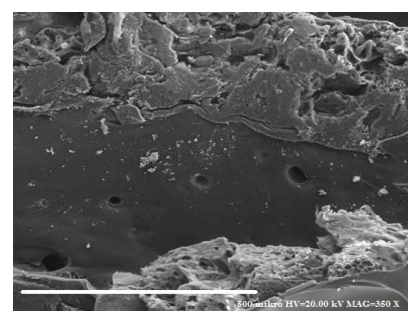

(b)

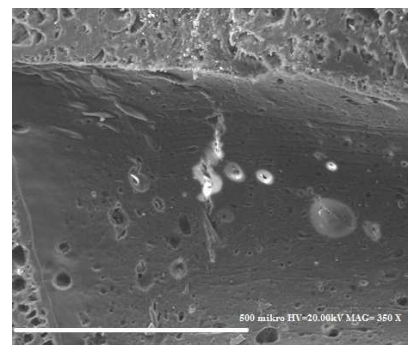

(d)

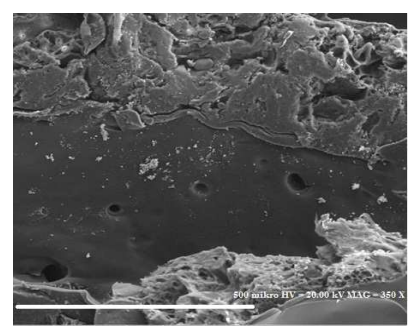

(f)

Fig 2. Hollow fiber PLGA-collagen coating chitosan $1 \%$ wt with magnification $100 \times$ (a), inner surface of hollow fiber PLGA-collagen coating chitosan $1 \%$ wt with magnification $350 \times(b)$, Hollow fiber PLGA-collagen coating chitosan $2 \%$ wt with magnification $150 \times(\mathrm{c})$, inner surface of hollow fiber PLGA-collagen coating chitosan $2 \%$ wt with magnification $350 \times$ (d), Hollow fiber PLGA-collagen coating chitosan $3 \% \mathrm{wt}$ with magnification $150 \times(\mathrm{e})$, inner surface of hollow fiber PLGA-collagen coating chitosan $3 \%$ wt with magnification $350 \times(\mathrm{f})$ 


\section{Hemolytic Test}

For hemolysis test, the percentage of coagulation was calculated by using Eq. 1 :

$$
\% D=\frac{A_{\text {sample }}-A_{\text {negatif }}}{A_{\text {positif }}-A_{\text {negatif }}} \times 100 \%
$$

Table 3. Hemolysis Result

\begin{tabular}{cc}
\hline Sampel & $\% \mathrm{D}$ \\
(Concentration of Chitosan) & $(\%)$ \\
\hline $1 \% \mathrm{wt}$ & 63.8 \\
$2 \% \mathrm{wt}$ & 15 \\
$3 \% \mathrm{wt}$ & 8.3 \\
\hline
\end{tabular}

\section{Discussion}

\section{Ultimate Tensile Test}

From Table 1, it was shown that the lowest chitosan concentration ( $1 \% \mathrm{wt})$ had highest ultimate tensile strength $(5.306 \mathrm{Mpa})$ while the value for $2 \%$ and $3 \%$ were almost similar. This phenomenon might be caused by an increased rate of chitosan infiltration through nanofiber pores due to smaller concentration. Thus, the mechanical strength was increased. The increase of tensile strength was also was attributed to the stronger interfacial adhesion between polymer and coater [3].

\section{Citotoxicity Test}

A material is toxic if the value of optical density was less than $60 \%$. The result of living cell precentage of samples were more than $60 \%$ and it could be concluded that material was a nontoxic material [4].

\section{Morphological Analysis}

Based on SEM characterization, the thickness of sample with coating $1 \% \mathrm{wt}$ was $0,3 \mu \mathrm{m}$ and the porous was $41,32 \mu \mathrm{m}$. The thickness of sample with coating $2 \% \mathrm{wt}$ was $0,4 \mu \mathrm{m}$ and the porous was $79,76 \mu \mathrm{m}$. The thickness of sample with $3 \% \mathrm{wt}$ of coating was $0,49 \mu \mathrm{m}$ and the pores were $108,95 \mu \mathrm{m}$ in diameter. A big number of pores showed that the infiltration of chitosan particle was low due to its high solution viscosity. In contrary, small number of pores showed high density of chitosan particles in the hollow fiber that caused a higher ultimate strength [5].

\section{Hemolytic Test}

High percentage of coagulation showed that there were many thromboses [6]. Thrombosis can be prevented by making the inner surface of hollow fiber smoother [6]. Since the inner surface of sample with $3 \%$ wt of chitosan was thicker, the thrombosis can be inhibited [7].

\section{Conclusion}

1. The highest tensile strength is provided by sample with $1 \% \mathrm{wt}$ chitosan caused by an increased rate of chitosan infiltration through nanofiber pores due to smaller concentration

2. The result of living cell procentage of samples are more than $60 \%$ and it could be concluded that the material is a nontoxic material

3. High chitosan concentration provides a big number of pores because the infiltration of chitosan particle is low due to its high solution viscosity. In contrary, Low chitosan concentration provides a small number of pores due to better infiltration of particle and it causes a higher ultimate tensile strength

4. Sample with highest chitosan concentration provides the lowest coagulation because thick concentration of chitosan makes inner surface of vascular graft smoother. 


\section{Acknowledgements}

Our great gratitude is delivered to Directorate of Higher Education (DIKTI) Ministry of National Education for funding through student creativity program. This investigation and the paper were supported in part, by Mrs. Siti Wafiroh, Ms. Vita, Ms. Mahdiya Nayla, Ms. Azisya AK and all the parties involved in the completion of this paper.

\section{References}

[1] Roger VL, Go AS, Lloyd-Jones DM, Benjamin EJ, Berry JD, Borden WB, et al. Heart disease and stroke statistics. 2012 update: a report from the American Heart Association.Circulation. 2012;125(1):e2-220.

[2] Kim, Mi Jin. et. al. In vitro and in vivo Application of PLGA Nanofiber for Artificial Blood Vessel. Macromolecular Research, Vol. 16, No. 4, pp 345-352 (2008)

[3] Polymer society, Polymer nanocomposites. Woodhead publishing and Maney publishing. Boston, New York.

[4] Spielmann, H., et al. The ECVAM International Validation Study on In VitroTests for Acute Skin Irritation: Report on the Validity of the EPISKIN and EpiDerm Assays and on the Skin Integrity Function Test. ATLA 35, 559-601, 2007

[5] Chawla, N and Deng, X. Effect of density in the microstructure and the mechanical behavior of powder metallurgy Fe-Mu-Ni steels. Mechanical Behavior of Materials Facility, Arizona State University

[6] Vijayanand, K.; Deepak, K.; Pattanayak, D.K.; Rama Mohan, T.R. \& Banerjee, R. (2005). Interpreting Blood-Biomaterial Interactions from Surface Free Energy and Work of Adhesion. Trends in Biomaterials and Artificial Organs, Vol.18, No.2, (January 2005), pp. 73-83, ISSN 0971-1198

[7] Fink, H., et al. 2011. An in vitro study of blood compatibility of vascular grafts made of bacterial cellulose in comparison with conventionally-used graft materials. Journal of Biomedical Materials Research Part A, 97A, 52-58. 
Materials, Industrial, and Manufacturing Engineering Research Advances 2

10.4028/www.scientific.net/AMR.1125

\section{Composite of Poly Lactid Co-Glycolic Acid (PLGA)-Collagen Coated by Chitosan as Candidate of Hollow Fiber Small Diameter Vascular Graft}

10.4028/www.scientific.net/AMR.1125.411

\section{DOI References}

[2] Kim, Mi Jin. et. al. In vitro and in vivo Application of PLGA Nanofiber for Artificial Blood Vessel. Macromolecular Research, Vol. 16, No. 4, pp.345-352 (2008).

$10.1007 / \mathrm{bf03218527}$

[3] Polymer society, Polymer nanocomposites. Woodhead publishing and Maney publishing. Boston, New York.

10.1016/b978-0-85709-777-4.50020-6

[7] Fink, H., et al. 2011. An in vitro study of blood compatibility of vascular grafts made of bacterial cellulose in comparison with conventionally-used graft materials. Journal of Biomedical Materials Research Part A, 97A, 52-58.

10.1002/jbm.a.33031 